\title{
Balancing Biography and Institutional History: Eric Worrell's Australian Reptile Park
}

\author{
NANCY CUSHING AND KEVIN MARKWELL
}

Biographies are like the fifty-foot brontosaurus in the museum -600 barrels of plaster and nine old bones. ${ }^{1}$

Cince 1963, a life sized sculpture of a Diplodocus dinosaur has stood Soutside the Australian Reptile Park on the New South Wales Central Coast. Its presence links Waite's simile about biography with the project of writing the park's history. We are not writing a biography of the park's founder and long term director, Eric Worrell, but of the 'nine old bones' we have gathered together about the history of the Park, eight relate to Worrell. This raises the issue of how histories of institutions can be written without becoming de facto biography when a single person has played a dominant role in the institution. In the face of the focus on Worrell suggested by much 
of the evidence, we have sought ways of ensuring we are able to present the history of the whole Australian Reptile Park, not just of the man who stood at its centre for so many years.

This project began with the intention of writing a history of the Australian Reptile Park which would help to commemorate its fiftieth anniversary, initially planned for 2008. The researchers themselves embody the tension between the Worrell focus and the institutional focus. The instigator was Kevin Markwell, a scholar of leisure and tourism, who had been a regular visitor to the park at Somersby and to its earlier location at Wyoming just north of Gosford, and an admirer of Eric Worrell both as a self-educated herpetologist and the operator of a successful tourist attraction. When approached to become a co-researcher, historian Nancy Cushing, who is based at the Central Coast's only university campus, agreed on the strength of the importance of the institution to the region although she had very little knowledge of the Park's founder. In the local area, the original park at Wyoming is a fondly remembered icon of childhood for many and a point of pride as an attraction of national stature. But Worrell's own reputation has been compromised by financial problems and a growing problem with alcohol. Discussing possible approaches, the researchers decided that distancing the history of the Park from its founder would be necessary to produce a balanced account which demonstrated the Park's fifty year history as an entity shaped by a range of influential individuals and social forces.

Setting out with this agreed goal, approved by the Park's current owners Robyn and John Weigel, we began to encounter both theory and evidence which pressed the biographical form on us. Anderson's insightful study of Adelaide Zoo reminded us that in zoos, 'an illusion of Nature is created from scratch and re-presented back to human audiences in a cultural performance and achievement ${ }^{\prime 2}$ The Australian Reptile Park is a cultural performance and while offering due attention to the animals it displayed, it is to the human performers that we as historians must turn. Eric Worrell was undoubtedly the star of this show. We started to be less confident. Would it be possible to separate the founder and long term director from his creation?

As we began to gather material on the origins of the Park, the difficulty we faced became more evident. Eric Worrell was a man of 
great energy who lived a life of adventure and achievement, and left a wealth of evidence about his activities, relationships and interests, in his own publications. Worrell was born in 1924 and spent most of his boyhood in Paddington. His fascination with reptiles began with Sunday visits to LaPerouse. While his sister was busy with pony rides, Worrell stood fascinated around the enclosure in which George Cann conducted his snake show. ${ }^{3}$ He first observed and later assisted Cann with his snakes, learning about their characteristics and habits. Like Cann, Worrell wanted to show animals to others and by the age of ten had set up a zoo of rabbits, guinea pigs and a tortoise in the tiny backyard of his parents' home. ${ }^{4}$

Leaving school at thirteen, Worrell worked in a wide variety of jobs, many of them in country areas which allowed him to indulge his interests in reptiles. With the outbreak of war, he was employed by the Allied Works Council in various locations and was posted to the Northern Territory in 1942 as a member of the Civil Constructional Corps. First in Darwin and then in Katherine, Worrell worked as a blacksmith's striker when he had to and on herpetological research when he could. While he had a serious interest in herpetology, corresponding with and providing specimens to museum and university-based herpetologists, he was aware that entertainment could be used as powerful educational tool. In Katherine, Worrell had a sign on the door of his hut which read, 'Eric Worrell. Curator: Katherine Zoo and Museum. Snake Charmer. All hours'. ${ }^{5}$ He gave both formal and impromptu performances with his snakes, explaining their nature and habits and educating people about how snakebite should be treated, as well as eliciting admiration through his deft handling of potentially deadly snakes. ${ }^{6}$

After the war, Worrell returned to the Northern Territory where he spent time at Mataranka Homestead, researching local wildlife, collecting specimens for sale to museums and zoos and honing his presentation skills on the tourists who came to stay. ${ }^{7}$ Worrell accelerated his publishing career, which came to include eleven books and scores of articles in both scholarly journals and popular magazines. He returned to Sydney, married in 1948 and opened the Open Beach Aquarium at Umina on the NSW Central Coast in 1950. At the Aquarium, Worrell continued his distinctive mix of art and science, making a show of the milking of snakes of their venom. From 1951, this venom was the financial mainstay of the enterprise, being 
sold to the Commonwealth Serum Laboratories for their research into and later production of antivenom for a range of snakes' bites.

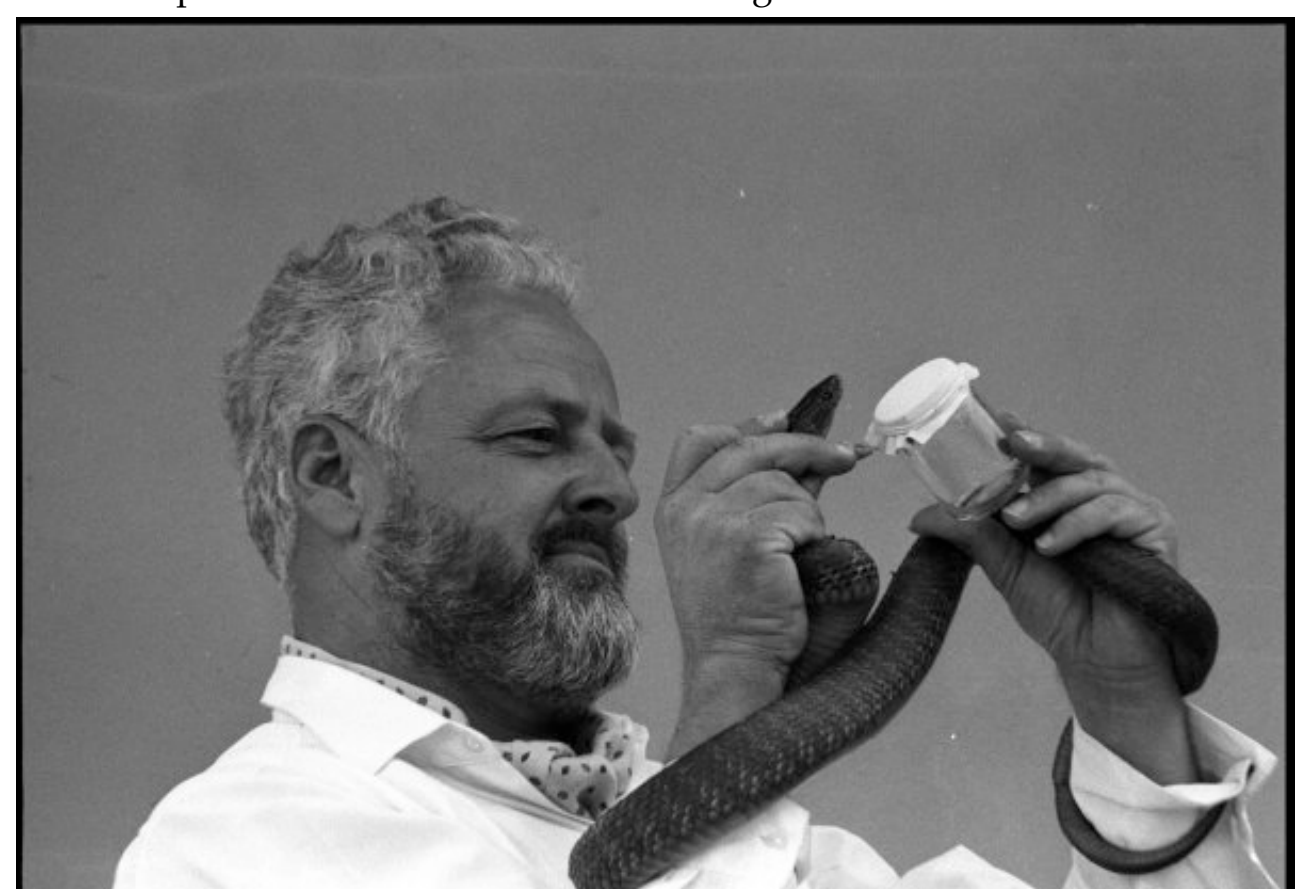

Eric Worrell: herpetologist, entrepreneur, showman, 21 April 1965, Australian Reptile Park, Gosford (John Mulligan, photographer. National Library of Australia, Record ID 3101068)

Worrell continued his prodigious output of written material and added to it with films for television after 1956. In 1958 he began to move his by then extensive collection of reptiles to a new site at Wyoming, just north of Gosford. Capitalising on his high profile as a media performer and author, he named the facility Eric Worrell's Australian Reptile Park and opened it to the public in 1959.

The Australian Reptile Park became the preeminent tourist attraction on the Central Coast. As well as continuing scientific work and innovating in the keeping and display of animals, Eric Worrell sought to attract visitors to his park with spectacle, most notably from 1963, the life sized dinosaur he had built in his parking lot. Worrell developed an extensive array of contacts on his research trips and through his work with reptiles. His associates included the naturalist Vincent Serventy, zoologist Jock Marshall and the artists photographer Jeff Carter and Russell Drysdale who sketched his portrait as 'The Snake Man' (c1965). Worrell was awarded the MBE in 
1970 for services to herpetology. He separated from his first wife in the late 1960s and married park employee Robyn Innes in 1973. Worrell's name was on the park, his family home was on its boundary, his parents and later his sister and niece lived and worked in the park and he attempted to control each decision that was made about its operations and long term direction. Worrell was the owner and director of the Australian Reptile Park, its hands on manager and a performer in a production of his own making.

In the mid 1970s, Eric Worrell's prodigious energy began to wane. He had long enjoyed a drink but in this decade, alcohol began to affect his daily life and his decision making ability. The staff of the park had to take more responsibility for its day-to-day running although Worrell still tried to keep control of any innovations or changes in direction. Worrell sought financial support from Gosford Shire Council and Taronga Zoo but neither of these bodies was ultimately willing to invest heavily in the enterprise. Worrell agreed to relinquish management of the Park to his by then ex-wife Robyn and local businessman Ed Manners. Although he publicly welcomed the new arrangement, Worrell personally found his changed circumstances difficult to accept and a combination of ill health and his problems with alcohol took their toll. In 1987, he suffered a heart attack and died at his home adjacent to the Park.

Although there is inevitably overlap, the Australian Reptile Park deserves a separate introduction. The park was initially run by Eric Worrell with just a few staff members. Through direct invitation or chance encounters, a handful of staff joined the park bringing expertise in animal husbandry gained informally and formally, in Australia and in Europe, with which they built up the park and its collection from the old citrus orchard which had previously occupied the site. B Class Zoo status was obtained in 1962, giving the Park the ability to import reptiles from overseas directly without the need for quarantine elsewhere. A range of Australian snakes were milked of their venom to supply the anti-venom and research requirements of the Commonwealth Serum Laboratories in Melbourne. The focus of displays was on reptiles including lizards, snakes and alligators, but the Park also featured a range of native mammals and birds, some held in enclosures and others ranging freely about site. Located on the Pacific Highway halfway between Sydney and Newcastle, the Park was well placed to attract holiday makers and catered to families with picnic areas, a miniature train and a swimming pool. 
Actual attendance records do not exist, but Worrell claimed that a couple of hundred thousand visitors came to the Park each year in the 1960s and early 1970s, particularly in school groups and during school holiday periods. In 1963, administrative assistance was required and Robyn Innes was hired, beginning her long association with the park. The 1960s and 1970s were the heyday of the Park which enjoyed a high profile as it exhibited new and exotic animals such as the New Guinea cuscus, which the Park was the first in Australia to breed in captivity, and the New Zealand tuatara - in new ways, such as the noctarium and platypusary.

The Park began to stagnate by the late 1970s as a consequence of lack of investment in park infrastructure, staffing problems, diminishing directions from Worrell himself and problems encountered in applying for permits to collect snakes for the venom program. Visitorship, staffing and the range and number of animals on display all went into a decline and ultimately into crisis, with staff remaining unpaid and the Park listed for sale by auction. This was averted in 1986 with a new management structure and investment from local businessman, Ed Manners. By the late 1980s, Robyn Worrell, with her new husband John Weigel, agreed that the site of the park was constraining its future development. They regained full financial control of the park and began a rejuvenation which culminated in 1996 with a move from the Wyoming site to an expansive bushland site at Somersby. After winning several tourism awards, the new Park was devastated by fire in early in 2000 but it has risen from those ashes, keeping the best of the past but innovating to include sophisticated museum-style exhibitions with live animals and animatronics as well as the more traditional naturalistic displays of animals in the open air.

These brief accounts of Worrell and the Park illustrate our difficulty. How are we to write a history of the Australian Reptile Park that is not a biography by default when one man established and dominated the park for almost three decades of its history? More particularly, how are we to portray Worrell as anything other than the leading man in the story of the Park, when he was not a selfdeprecating laboratory scientist but a snake wielding showman who garnered the spot light for himself in print, on film and at his eponymous Park? Is it possible or appropriate to write a history in 
which Eric Worrell is just one of a cast of characters who made contributions to the Park?

We have tried to discover a literature on the writing of institutional histories to offer guidance on striking a balance between biography and institutional history, but without success. Instead, we turned to the practical examples of histories of other natural history institutions. Is this a problem with which other zoo historians have had to grapple? It seems it is. Having consulted histories of the zoos in London (taken as the archetype of the modern zoo) and in three of Australia's capital cities, one theme is notable: each of these institutions has had very long term associations with one person in the role of director. London Zoo had Abraham Bartlett as its superintendent from 1859 until his death in 1897. ${ }^{8}$ At Melbourne Zoo, Albert le Souef was in charge between its commencement in 1870 and his death in 1902. He lived on site with his large family and, in an era when there was no specific training for zookeepers or administrators, he encouraged his sons to carry on the family trade. ${ }^{9}$ His three sons became directors of zoos in Melbourne, Perth and Sydney, creating a le Souef zoo era which extended over seven decades and from the Pacific to the Indian Oceans. ${ }^{10}$

Adelaide Zoo had its own dynasty, the Minchins, which continued for three generations between 1882 and 1940, the younger members of which were born in the zoo and the last of whom had his ashes scattered there. ${ }^{11}$ In Sydney, refrigerator manufacturer, Sir Edward Hallstrom, joined the Taronga Zoological Park Trust and ran the zoo almost as a personal fiefdom between 1941 and $1967 .{ }^{12}$ Most of the histories of these zoos have at least one chapter named for these long term employees. One advantage these historians enjoyed over us is the age of their institutions and therefore, the timeframe of their projects. Initiated by acclimatisation or zoological societies in the mid nineteenth century, none of the long-term directors of these zoos was also a sole founder and none dominated the form and vision of the institution for more than half of its existence. With the Australian Reptile Park only approaching its jubilee, one individual can still loom very large.

Determined to maintain our focus on the park, we turned to the written sources generated by and about the Park. With Eric Worrell as director, 'marketing manager' and general mastermind of the Park until the mid 1980s, it is not surprising that he also dominates the records of the Park. After having read his books and dozens of his 
articles in the Mitchell Library, explored the promotional literature in tourist publications and exhausted indexed newspaper references to the Park, it was clear that much of what appeared in the press during Worrell's lifetime was based on information provided by Worrell and that it rarely offered an objective or critical perspective. We turned to the archives of the park itself which were held in a shipping container down a dirt track on the Park grounds. Inside were large wooden file drawers pulled from their cabinets filled with clearly labeled files on a wide variety of topics. As we slowly worked through the files, the focus on Worrell was exacerbated. The archived records of the Park are his records, a mixture of official and private correspondence, financial statements, drafts of papers and personnel files, revealing still more of Worrell's personal and professional life but showing the park largely through his lense. The written records almost exclusively portray Worrell's view of events and people.

Anticipating the limitations of these written records early on, we had designed the project to include a large oral history component. As its proponents since the 1970s have claimed, oral history can help critically to examine other forms of evidence and to fill the gaps in that evidence. ${ }^{13}$ According to Paul Thompson, 'It allows heroes not just from the leaders, but from the unknown majority of the people'. ${ }^{14}$ Oral history taps into the personal history people develop for themselves to help them define a sense of identity and reflects their own world view. ${ }^{15}$ As in this case, it can allow the otherwise voiceless to record their version of events and to offer a counterpoint to the authoritative voice of written documents, reintroducing the multiplicity of view points from which the past was experienced. ${ }^{16}$ For institutional histories in particular, as Gardner has argued with regard to the history of charitable foundations, a creative tension exists between those who establish such organisations and the staff who run them, 'a tension that is not easy to discern in minutes, annual reports or publications' but which can be documented through oral history which shows how the founders' 'intentions have been reformulated over time' ${ }^{17}$

We were particularly keen to seek out those people who had played key roles in sustaining the Park including those who tended animals, built enclosures, installed heating and light systems and layed out and cared for the grounds. ${ }^{18}$ Ethics approval was secured from our employer, the University of Newcastle, following national 
guidelines for oral history research. Potential interviewees were provided with a written explanation of the nature of the project and the limits of their participation in it should they agree to be interviewed, including the right to end their association with the project at any time, to review transcripts of interviews and manuscripts based on them and to be referred to by a pseudonym in any resultant publications.

The process of gaining ethics approval while time consuming was straight forward and prompted us to consider more deeply both our methodology and the types of evidence to be sought through this means. The majority of the people who were approached agreed to participate and although many initially claimed they would have little to say to us, the interviews, lightly guided by a set of written questions, were lively and informative, revealing a genuine commitment to the park as an institution. To date, we have conducted fifty interviews with people associated with the Park, from long and short term employees and volunteers, to Worrell relatives and friends, to scientists from the Commonwealth Serum Laboratory, Taronga Zoo and the Australian Museum. Oral history has offered us a way around the Eric Worrell focus as it illuminates what others were doing at the park and how they remembered their associations with it. The fruits of oral history research can be subtle, providing a range of alternative views which complement or vary that available in written texts. This will be illustrated with reference to one incident in the Park's history which was examined via a range of sources. On 12 April 1976, dramatic photographs appeared in the Sydney newspaper, the Sun. They featured a fifteen-year-old keeper at the Australian Reptile Park nearly drowning in the Park's swimming pool. A fifteen-foot scrub python was wrapped around his neck and chest and Eric Worrell was by his side fighting to rescue him. The accompanying story explained that the snake had been placed in the pool to ease the shedding of its skin, but that it had turned on its keeper and Worrell had intervened. One of the photographs was sent around the world, appearing in newspapers in the UK, the US and Europe and being awarded the Walkley Award for the best news picture of 1976. We wondered why the photographer had been there on the day of the incident, but assumed his presence was coincidental.

During our interview with him some thirty years later, the keeper, Steve McEwan, had a somewhat different recollection. 


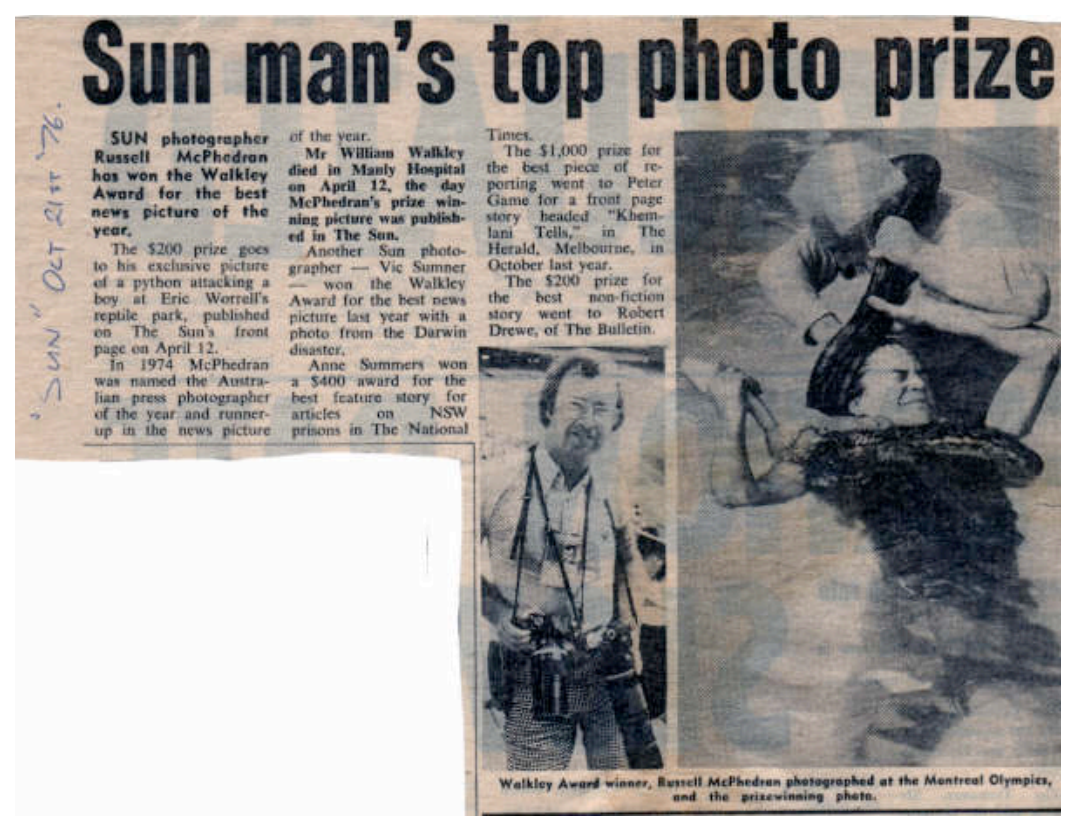

The dramatic photograph of Eric Worrell wresting a python in the pool at the Australian Reptile Park won the Walkley Award for the best news picture of 1976 (Sun, 21 October 1976)

McPhedron had come to the Park that day specifically to take eyecatching photographs. McEwan had obligingly posed with the snake in the pool, assisting with the snake's shedding process. But the photographer was not satisfied with the ordinary drama of the care of captive reptiles and asked whether some additional shots could be taken. It was then that the snake, becoming cold and tired of the handling, began to struggle in the boy's grip and that Worrell, fully clothed, joined McEwan in the pool. Worrell's intervention created an even more dramatic spectacle and a potentially dangerous situation was captured for the world to see.

A scrapbook of clippings about the park, a copy of which is now held by the Gosford Library, and which had been donated by a former staff member who had worked at the park at the time, also suggests that the event had been initially staged for the benefit of the photographer, corroborating McEwan's recollections, although the annotations on the scrap book further support the contention that the incident did in fact turn out to be a hazardous encounter for the keeper, and the look of anxiety on the boy's face was entirely real. ${ }^{19}$ Sometimes supported by documentary evidence and sometimes not, 
hundreds of hours of oral history testimony from a wide variety of interviewees have provided us with the necessary range of perspectives to develop a rounded institutional history.

However, the gathering of oral histories has not been without its own challenges and frustrations which once again foreground the tension between institutional history and biography. With such a close identification between Worrell and the Park, willingness to share memories of it becomes entangled with personal resentment or loyalty. Some people associated with the Park have been open with us and willing to provide personal and sometimes unflattering points of view. Others who became estranged from Worrell have been unwilling to participate. Their contributions to and experience of life in and around the park remain out of reach. Others who we know to have had strained relations with Worrell have responded to our approach but in the negative, generally pleading that they have little to say about Worrell, even though our focus is on the Park. The loss of their perspective impoverishes our history. One senior employee was initially reluctant to participate, but did enter into an ongoing email dialogue. That virtual and invaluable conversation has now been going on for several years and extended to include photographs and documents.

Those who willingly agree to participate in oral history interviews are often reluctant to venture into areas which they feel reflect badly on Eric Worrell. Through loyalty or respect for one who has passed on, they avoid the lines of questioning that would lead to less than flattering accounts. On the issue of Worrell's alcoholism, some who were very close to Worrell have offered alternative explanations for his behaviour or have justifications for why he became dependent on alcohol, related to his years of exposure to snake venom. Whether these explanations are genuine beliefs of the informants is not clear but they seem to show a strategy of protecting an old friend or associate, which is entirely understandable.

Although there may be a natural tendency for informants to try to provide evidence which meets the perceived aims of the researchers, we have heard a range of opinions about Eric Worrell as a man, a herpetologist and an employer and believe that we have effectively communicated our desire for the best account of the past they can provide. In the case of some key informants, we have arranged less formal repeat interviews which have brought out additional perspectives. Within these constraints, oral history has informed our 
interpretation and enriched our writing of histories by revealing variations in versions of the past.

Is it possible to disentangle the life of Eric Worrell from the life of his Park? Is that even a sensible aspiration? The event which triggered the writing of this book was the jubilee of the Park which was scheduled for 2008 but which we have now found should be in 2009. For more than half of that period, Eric Worrell was involved in the form, direction and day to day operation of the Australian Reptile Park. But since he stepped aside in the mid 1980s, it has been run by his former wife Robyn Weigel and her husband, Robyn now having had a longer association with it than has any other person. To write the history of the Park as a biography of Eric Worrell would be unfair to Robyn and John Weigel, to Lyn Abra who became known as the Spider Lady during her many years of employment and to all of the keepers and managers who have committed their expertise and energy to the Park.

In late June 2007, one the Reptile Park's star attractions, huge battle scarred Eric the Crocodile, died after the severe Queen's Birthday storms. The power supply which kept his enclosure heated was disrupted and this creature of the tropics could not withstand the cold conditions. The crocodile had been given the name 'Eric' on his arrival at the Park in 1990 in memory of Worrell. The death of Eric the Crocodile is a timely reminder that one's legacy extends only so far. ${ }^{20}$ The history of the Park is difficult to disentangle from the biography of its founder in its early sections but the Park has outlived him. Like all zoos, the Australian Reptile Park 'inscribe[s] various human representational and material strategies for domesticating, mythologizing and aestheticizing the animal universe ${ }^{\prime 21}$ These strategies are not the work of one man. They arise from the society at large and are implemented and altered by all involved in the running of the institution. Despite the ease of a life history structure, the seductiveness of the wealth of written material, the preconceptions of oral history informants and the preferences of potential publishers, we will continue with our intention of writing a balanced institutional history which examines the role of the park in the development of attraction based tourism, herpetology, the exhibition of native animals and antivenom research. 


\section{ENDNOTES}

${ }^{1}$ P.B. Waite, 'Reefs Unsuspected: Historians and Biography in Canada, Australia and Elsewhere', Macquarie University, Sydney, 1983, p5.

${ }^{2}$ Kay Anderson, 'Culture and Nature at the Adelaide Zoo: at the frontiers of "human" geography', Transactions of the Institute of British Geographers, no 20, 1995, p275.

${ }^{3}$ Eric Worrell, 'I like snakes', Cavalcade, March 1949, p58; Joyce Worrell Veryt interview, 10 October 2005.

${ }^{4}$ Worrell, 'I like snakes', p59; Joyce Worrell Veryt interview, 10 October 2005; Eric Worrell, Song of the Snake, Angus and Robertson, Sydney, 1958, p145.

${ }^{5}$ Photograph held by Australian Reptile Park.

${ }^{6}$ See, for example, the accounts of Worrell's snake demonstrations in Roland Robinson, The Drift of Thing: An Autobiography, 1914-52, MacMillan, Melbourne, 1973.

${ }^{7}$ Eric Worrell, 'I like snakes', pp59-60.

${ }^{8}$ J. Barrington-Johnson, The Zoo: The Story of London Zoo, Robert Hale, London, 2005, p47. This history includes a chapter named for Bartlett and one named for Sir Thomas Raffles who initiated the idea the zoo, but died a year before it opened.

${ }^{9}$ Catherine de Courcy, Evolution of a Zoo: A History of Melbourne Zoological Gardens, 1857-1900, Quiddlers Press, Auburn, Victoria, 2003, p37.

${ }^{10}$ Dudley le Souef succeeded his father as director of Melbourne Zoo until 1923, Ernest became director of the Perth Zoo in 1897 retiring in 1932 and youngest son Albert was director of Moore Park Zoo and its successor Taronga Zoo from 1903 until 1940. A. Dunbavin Butcher, 'Le Souef, William Henry Dudley (1856 - 1923)', joint entry for the le Souef brothers, Australian Dictionary of Biography on line,

$<$ http:/ / www.adb.online.anu.edu.au/biogs/ A100075b.htm> accessed 21 September 2007; de Courcy, Evolution of a Zoo, p78.

${ }^{11}$ Joyce Gibberd , 'Minchin, Alfred Corker (1857 - 1934)', Australian Dictionary of Biography on line, $<$ http:/ / www.adb.online.anu.edu.au / biogs / A100513b.htm>, accessed 21 September 2007.

${ }^{12}$ Ronald Strachan, Beauty and the Beasts: A Fascinating History of Taronga Zoo, Western Plains Zoo and their antecedents, Zoological Parks Board of NSW, Sydney, 1991, p47.

${ }^{13}$ Beth M. Robertson, Oral History Handbook, $5^{\text {th }}$ Edition, Oral History Association of Australia, South Australian Branch, Unley, South Australia, 2006, p3.

${ }^{14}$ Quoted in ibid, p3.

${ }^{15}$ Paul Ashton, On the Record, A Practical Guide to Oral History, North Sydney Council, Sydney, 1994, p4.

${ }^{16}$ Paul Thompson, 'History and the Community', in David K. Dunaway and Willa K. Baum (eds), Oral History: An Interdisciplinary Anthology, American Association for State and Local History, Nashville, 1984, p40.

${ }^{17}$ Joel R. Gardner, 'Oral History and Philanthropy: Private Foundations', Journal of American History, vol 79, no 2, 1992, p605.

${ }^{18}$ Anderson, 'Culture and nature at the Adelaide Zoo', p283. 
${ }^{19}$ Australian Reptile Park scrapbook, Gosford City Library, Local Studies Section.

${ }^{20}$ The crocodile which replaced Eric in September 2007 was named Elvis.

${ }^{21}$ Anderson, 'Culture and nature at the Adelaide Zoo', p276. 